\title{
A AMAZÔNIA BRASILEIRA EM MILTON HATOUM: UMA LEITURA DE RELATO DE UM CERTO ORIENTE E DOIS IRMÃOS
}

Francisco Aquinei Timóteo Queirós ${ }^{1}$

Francielle Maria Modesto Mendes ${ }^{2}$

\section{RESUMO}

O estudo centra-se na análise dos romances Relato de um certo oriente (1989) e Dois irmãos (2000), do escritor manauense Milton Hatoum. Constata-se nas obras, a subversão da paisagem que marca as narrativas sobre a Amazônia brasileira. 0 olhar hatouniano desloca-se dos cenários de uma "floresta amedrontadora" e do mote reiterado dos ciclos da borracha para ancorar-se na paisagem da cidade - com seus movimentos e problemáticas - tendo como fio condutor os sujeitos migrantes. Nas duas obras, o autor promove a abertura do romance amazônico para temáticas que envolvem as disputas, a memória, os dramas familiares e a prevalência de uma narrativa urbana. O artigo apoia-se nas reflexões de Homi Bhabha (2013), Roger Chartier (2002), entre outros.

\section{PALAVRAS-CHAVE}

Milton Hatoum. Relato de um certo oriente. Dois irmãos. Narrativa.

\section{THE BRAZILIAN AMAZON OF MILTON HATOUM: A READING OF RELATO DE UM CERTO ORIENTE (THE TREE OF THE SEVENTH HEAVEN) AND DOIS IRMÃOS (THE BROTHERS)}

\section{ABSTRACT}

This study focuses on the analysis of the novels Relato de um certo oriente (1989) and Dois irmãos (2000), by the Amazonian writer Milton Hatoum. In the works, we observe the subversion of the landscape that marks the narratives about the Brazilian Amazon. Hatoum's gaze displaces itself from the scenarios of a "frightening forest" and the reiterated motto of the rubber cycles to relocate in the landscape of the city - with its movements and problems - using migrant subjects as its guiding thread. In both works, the author promotes the opening of the Amazonian novel to topics that involve disputes, memory, family dramas and are prevalently set in urban narratives. The article is based on the reflections of Homi Bhabha (2013), Roger Chartier (2002) and others.

\section{KEYWORDS}

Milton Hatoum. Relato de um certo oriente. Dois irmãos. Narrative.

\footnotetext{
1 Doutorando do Programa de Pós-Graduação em Ciências da Comunicação pela Universidade do Vale do Rio dos Sinos (Unisinos), Mestre em Letras: Linguagem e Identidade pela Universidade Federal do Acre (2013) e professor efetivo dessa mesma Instituição Federal de Ensino, com atuação no Curso de Comunicação Social/Jornalismo.

2 Doutora em História Social pela Universidade de São Paulo (2013), Mestre em Letras: Linguagem e Identidade pela Universidade Federal do Acre (2008) e professora efetiva dessa mesma Instituição Federal de Ensino, com atuação no Curso de Comunicação Social/Jornalismo e no Programa de Pós-Graduação em Letras: Linguagem e Identidade.
} 
Eu sempre começo meus romances pelo fim.

Eu preciso saber aonde eu vou chegar.

Se eu souber aonde vou chegar, o resto que é quase tudo, que é tudo, é a travessia (Milton Hatoum ${ }^{3}$ ).

\section{Introdução}

0 presente estudo discute de que forma a Amazônia é narrada em duas obras de Milton Hatoum: Relato de um certo oriente (1989) e Dois irmãos (2000). O autor é amazonense, nasceu em Manaus no ano de 1952. Além desses dois romances, publicou os romances Cinzas do Norte (2005) e Órfãos do Eldorado (2008). Ensinou literatura na Universidade do Amazonas e na Universidade da Califórnia, em Berkeley.

As obras aqui estudadas se diferenciam de outras que têm a Amazônia como cenário, caso de A Selva, Ferreira de Castro; Terra Caída, José Potyguara; Seringal, Miguel Jerônimo Ferrante; Coronel de Barranco, Cláudio de Araújo Lima. A diferença se dá porque as histórias hatounianas são urbanas, se passam predominantemente em Manaus. As personagens

Frase dita pelo autor no programa Globo News Literatura sobre a estreia da minissérie Dois irmãos, na TV Globo, em 7 de janeiro de 2017. enfrentam dramas familiares e problemas psicológicos intensos, que se sobrepõem aos problemas de relacionamento com o meio natural. Diante disso, o conflito ser humano/natureza, tão comum na literatura que tem como cenário a Amazônia, não é o norte nas obras aqui estudadas.

As obras citadas no primeiro parágrafo deste texto são marcadas por personagens que, em sua maioria, são seringueiros ou seringalistas. Habitam uma floresta que é rica em fauna e flora, mas, por vezes, é tida como amedrontadora. Nesses textos, os espaços da cidade são suprimidos ou narrados somente no contexto dos dois ciclos econômicos da borracha.

Essas literaturas concentramse na manutenção de algumas representações e imaginários sobre a Amazônia brasileira. Sabe-se que desde a chegada dos primeiros europeus à região, nos séculos XVI e XVII, o lugar é observado pela dicotomia inferno verde/paraíso tropical e as populações são identificadas como exóticas e pitorescas. Essas abordagens fazem com que o discurso construído ao longo 
dos tempos seja de população homogênea e estereotipada (MENDES; QUEIRÓS, 2014).

Para Homi Bhabha, o conceito de cultura homogênea está "em profundo processo de redefinição" (2013, p. 25). Diante disso, o Hatoum se afasta dessa visão tradicional que diz ser a Amazônia brasileira um local distante, isolado, primitivo, onde a floresta devoradora é protagonista, se sobrepondo aos problemas humanos.

Em entrevista dada a Luiz Enrique Gurgel, na revista Na ponta do lápis, em 2008, o autor assume sua identificação com Manaus, e diz que a cidade tem ligações com a floresta, mas, mesmo assim, ele não se sente filho dessa selva:

o lugar da minha ficção é o Amazonas. Muitas vezes as pessoas não entendem isso. A minha Amazonas é uma Amazonas metropolitana, urbana. Eu não sou filho da floresta, a floresta não é o meu habitat. A minha literatura é urbana, mas com muitos vínculos com a floresta, o rio. Eu acho que o lugar da literatura é o lugar da infância. Onde eu vou, levo Manaus comigo. Mas não uma Manaus qualquer. É a Manaus do começo dos anos 1960, fim dos anos 1950 (HATOUM apud GURGEL, 2008, online).
0 autor não nega as imbricações cidade/floresta, apenas observa a região e sua gente sem os antolhos da hostilidade, analisando as multiplicidades e os entrecruzamentos culturais, os conflitos internos, as buscas de identidades e as transformações por quais passam suas personagens e a própria cidade de Manaus.

\section{Relato de um certo oriente: o enredo}

Em Relato de um certo oriente, os dramas de uma família árabe e os problemas psicológicos das personagens estão no centro da narrativa. A obra é narrada pela filha adotiva de Emilie ${ }^{4}$, que é a personagem central da história. A filha organiza relatos de Hakim (o filho preferido), Dorner (o fotógrafo alemão amigo da família), o marido de Emilie e

4 A personagem Emilie reaparece na obra Dois irmãos como amiga de Zana: “Não quer ver mais ninguém', dizia Zana quando batiam a porta. Só com uma visita ela foi paciente: a velha matriarca Emilie, que raramente passava em casa. Quando aparecia, Emilie ouvia tudo, todos os lamentos, e depois falava em árabe, a voz alta, mas tranquila, sem alarde" (HATOUM, 2000, p. 250). E reaparece no conto "A natureza ri da cultura", publicado na obra A cidade ilhada: "Ainda me lembro da voz de Emilie, a matriarca. Na minha infância, eu a escutava cantar e rezar, não em árabe, sua língua materna, mas em francês, sua língua adotada" (HATOUM, 2009, p. 95). 
Hindié Conceição, a amiga íntima da matriarca.

A narradora inominada sofre de transtornos psicológicos, por isso esteve em uma clínica de repouso em São Paulo. Após quase vinte anos, retorna a Manaus: "à casa de sua infância na tentativa de reconstruir, por meio das lembranças e vãos do esquecimento um mundo perdido e uma casa desfeita" (SILVA, 2010, p. 109). Ela chega em busca do passado, da sua identidade e de algumas respostas que podem indicar a origem de seus traumas e o porquê de ocupar uma posição na margem de sua família. Como afirma Homi Bhabha, "a identidade é reivindicada a partir de uma posição de marginalidade ou em uma tentativa de ganhar o centro" (2013, p. 284).

A partir dos relatos dos familiares e amigos, a narradora, filha adotiva, organiza algumas histórias vividas por sua família. Por intermédio dos recursos da memória, ela tece os fios da narrativa. Esse aspecto memorialístico das obras de Hatoum é justificado pelo próprio autor:

Não há literatura sem memória.
A pátria de todo escritor é a infância. Eu acho que o momento da infância e da juventude é privilegiado para quem quer escrever. É onde a memória sedimenta coisas importantes: as grandes felicidades, os traumas, as alegrias e também as decepções. Certamente não estou falando da lembrança pontual e nítida. 0 que me interessa é a memória desfocada, a memória não lembrada. Isso é bom para a literatura porque aí é que se instala o espaço da invenção. Alguma coisa que você lembra, mas sem nitidez porque é isso que traz o espaço fluido, nebuloso e incerto daquilo que se vai narrar. Quer dizer, eu não sei exatamente o que aconteceu, mas sei que alguma coisa aconteceu no passado e é sobre isso que quero escrever. É como se uma frase dessa lembrança meio esfumada pudesse produzir mais 300 frases. Uma coisa puxa a outra. Então, você não faz esforço para se lembrar. Como dizia Clarice Lispector: "É você se lembrar de coisas que nunca aconteceram". Esse é o movimento que te leva à escrita: lembrar de coisas que poderiam ter acontecido (HATOUM apud GURGEL, 2008).

Emilie tinha quatro filhos, além da narradora e de seu irmão que vive em Barcelona: Hakim e Samara Délia, e os "dois, inomináveis, filhos ferozes de Emilie, que tinham o demônio tatuado no corpo e uma língua 
de fogo" (HATOUM, 2008, p.10). Samara teve uma filha na adolescência chamada Soraya Ângela, que nasceu surda-muda e morreu no natal de 1954, vítima de um acidente em frente da própria casa onde morava.

Por causa da gravidez, Samara foi rejeitada por toda a família, sobretudo, os irmãos: "Devia ter quinze ou dezesseis anos quando ficou grávida: era uma menina que brincava de boneca contigo, trepava em árvores para colher frutas, e fazia estrepolias que animavam a casa. Nada disso permaneceu após o nascimento da filha" (HATOUM, 2008, p. 125). Em uma de suas conversas com Hakim, ela revela que o desprezo do pai também a deixava muito triste: "Nada me fere mais do que o silêncio dele" (HATOUM, 2008, p. 136).

Hakim deixa o Amazonas e vai morar no sul do país. Ele era o filho querido, o único que entendia árabe: “(...) quando ríamos, era a vida mesma que parecia interromper seu curso, porque era um riso convulsivo, engrolado, quase nefasto" (HATOUM, 2008a, p. 117).

Emir, irmão de Emilie, suicidou-se em um rio. Antes de sua morte, ele foi fotografado na praça da cidade pelo alemão: "Dorner fotografou Emir no centro do coreto da praça da Polícia. Foi a última foto de Emir, um pouco antes de sua caminhada solitária que terminaria no cais do porto e no fundo do rio" (HATOUM, 2008, p. 67). 0 fotógrafo ressalta que Emir não era um imigrante como os demais. Ele não andava pela floresta em busca de animais selvagens, banhos de rio $\mathrm{e}$ experiências com moradores da região:

Emir não era como os outros imigrantes, não se embrenhava no interior enfrentando as feras e padecendo as febres, não se entregava ao vaivém incessante entre Manaus e a teia de rios, não havia nele a sanha e a determinação dos que desembarcavam jovens e pobres para no fim de uma vida atormentada ostentarem um império (HATOUM, 2008, p. 69).

o marido árabe de Emilie chegou pela primeira vez na Amazônia na busca de um tio chamado Hanna, todavia ao desembarcar na região não o encontrou mais vivo. As cartas enviadas direto da Amazônia pelo parente sustentam alguns estereótipos $^{5}$ narrados sobre Para Homi Bhabha (2013), o ato de 
a região amazônica brasileira, dos quais Hatoum tenta, em alguns momentos, se distanciar. Hanna narrava um lugar repleto de aventuras e desafios, mas ao mesmo tempo de paisagem exuberante:

[As cartas] Relatavam epidemias devastadoras, crueldades executadas com requinte por homens que veneravam a lua, inúmeras batalhas tingidas com as cores do crepúsculo, homens que degustavam a carne de seus semelhantes como se saboreassem rabo de carneiro, palácios com jardins esplêndidos, dotados de paredes inclinadas e rasgadas por janelas ogivais que apontavam para o poente, onde repousa a lua de ramadã. Relatavam também os perigos que haviam enfrentado: rios de superfície tão vasta que pareciam um espelho infinito; a pele furta-cor de um certo réptil que o despertou com o seu brilho intenso quando cerrava as pálpebras na hora sagrada da sesta; e a ação de um veneno que os nativos não usavam para fins belicosos, mas que ao penetrar na pele de alguém, fazia-lhe adormecer, originando pesadelos terríveis, que eram a soma dos momentos mais

estereotipar não é estabelecimento de uma falsa imagem que se torna o bode expiatório de práticas discriminatórias. É um texto muito mais ambivalente de projeção e introjeção, estratégias metafóricas e metonímicas, deslocamento, sobredeterminação, culpa, agressividade, o mascaramento e cisão de saberes 'oficiais' e fantasmagóricos. infelizes da vida de um homem (HATOUM, 2008, p. 80-81).

Por intermédio de Hanna, Hatoum diz ao seu leitor que algumas representações locais são costumeiras, que sempre haverá um estrangeiro se deslocando para Amazônia em busca de povos primitivos, contato com a natureza, com os rios e os animais. Como afirma Roger Chartier, as representações "são sempre determinadas pelos interesses de grupo que as forjam" (CHARTIER, 2002, p. 27). E, no caso da Amazônia brasileira, a narrativa sobre a região é elaborada, muitas vezes, pelo 'outro' e os seus interesses particulares.

Ao contrário do tio Hanna que narrava uma Amazônia exótica e perigosa, ocupada por uma população de ignorantes e muitos animais selvagens, o alemão e fotógrafo Dorner "procurava contestar um senso comum bastante difundido aqui no norte: o de que as pessoas são alheias a tudo, e que já nascem lerdas e tristes e passivas; seus argumentos apoiavam-se na sua vivência intensa na região" (HATOUM, 2008, p.93).

0 casamento da matriarca 
Emilie era marcado por diferenças culturais. Emilie não conhecia o interior do Amazonas, seu mundo era Manaus, ao contrário do marido que já navegara nos rios da Amazônia. "Emilie, ao contrário de meu pai, de Dorner e dos nossos vizinhos, não tinha vivido no interior do Amazonas. Ela, como eu, jamais atravessara o rio. Manaus era o seu mundo visível" (HATOUM, 2008, p. 102).

Ela e o marido mulçumano acordaram que a diferença de religião não seria problema: "Emilie e o marido praticavam a religião com fervor. Antes do casamento haviam feito um pacto para respeitar a religião do outro, cabendo aos filhos optarem por uma das duas ou por nenhuma" (HATOUM, 2008, p.77). 0 companheiro ignorou por um tempo algumas práticas do cristianismo da mulher, enquanto lia fervorosamente o Alcorão:

Ele encarava com naturalidade e compreensão o fervor religioso de Emilie. Tolerava as festas cristãs, mas se alheava com um desdém perfeito das preces elaboradas por Emilie, fazia vista grossa às imagens e estátuas de santos, eafastava-se do quartinho de costura onde as duas mulheres cortavam e picotavam retângulos de papel vegetal para confeccionar santinhos coloridos que seriam doados às órfãs internas do colégio Nossa Senhora Auxiliadora durante a primeira comunhão (HATOUM, 2008, p.49).

Contudo, a convivência foi tornando-se complicada porque Emilie não gostava do jejum que o marido fazia, escondia o Alcorão e isso o irritava muito. Há uma passagem no livro em que ele tranca toda a casa em represália ao sumiço de seu livro de orações: "Só então soubemos que ela havia escondido o Livro e, que meu pai tinha vedado a casa para que o espaço entrevado impedisse todo ser humano de enxergar algo antes do reaparecimento do Livro" (HATOUM, 2008, p. 54).

A obra acentua os processos de hibridização cultural. Para Bhabha (2013), o hibridismo cultural emerge em momentos de transformação histórica, caso do deslocamento das personagens árabes para a região amazônica. A mistura das culturas está presente na decoração da casa onde moravam, nas refeições feitas em família, nas misturas de idiomas, nas religiões distintas do casal e em diversas outras situações. No trecho a seguir, é possível observar a diversidade cultural na 
decoração da casa:

Duas salas contíguas se isolavam do resto de casa. Além de sombrias, estavam entulhadas de móveis e poltronas, decoradas com tapetes de Kasher e de Isfahan, elefantes indianos que emitiam o brilho da porcelana polida, e baús orientais com relevos de dragão nas cinco faces (HATOUM, 2008, p. 8).

As reuniões familiares eram repletas de fartura gastronômica e alguns hábitos alimentícios causavam estranhamento tanto na filha adotiva quanto na empregada Anastácia Socorro, que não eram árabes:

No centro de um pátio iluminado pelo sol equatorial, homens e mulheres repetiam o hábito gastronômico milenar de comer com as mãos o fígado cru de carneiro. Não era a um ritual bárbaro ou ao sacrifício de um animal que eu assistia do quarto dos pais, mas sim a uma novidade assombrosa, a uma festa exótica que tanto contrastava com o ritmo habitual da casa (HATOUM, 2008, p.64-65).

(...) Elogiavam-se os temperos, os doces de semolina com nozes de mel, a compota de pétalas de rosa, que todos aspiravam demoradamente antes de provar. Alguns, temendo não ser convidados para o jantar do sábado - quando seria preparado o pernil de carneiro assado com tâmaras - esperavam ansiosos o momento da despedida, para que meu pai citasse a frase em que Deus permitia abrir-lhes as portas da casa para a ceia da manhã (HATOUM, 2008, p. 65).

Para a narradora, o alimento era algo tão importante na cultura dos pais que a mãe se sentia muito feliz quando os filhos comiam em grandes quantidades: "para fazê-la feliz bastava que um filho devorasse quantidades imensas de alimentos, como se o conceito de felicidades estivesse muito próximo ao ato de mastigar e ingerir sem fim" (HATOUM, 2008, p. 100).

A manutenção do idioma é outro aspecto cultural importante, que funciona como uma estratégia de ligação com as origens, por isso os encontros festivos com amigos orientais eram marcados por conversas em árabe:

A conversa era exclusivamente em árabe, salvo os cumprimentos de algum transeunte conhecido, ou a visita de um ou outro vizinho, alguns deles estrangeiros, como a família do poveiro Américo, os Benemou, do Marrocos, e Gustav Dorner, o rapaz de Hamburgo; todos amicíssimos de Emilie, e o último, além de amigo, tornou-se meu confidente (HATOUM, 2008, p.65).

Alguns aspectos sobre a cultura árabe, caso da língua, a gastronomia, entre outros, assim como os conflitos humanos das 
personagens e o desenvolvimento/ derrocada da cidade de Manaus também vão ser percebidos na obra Dois irmãos.

\section{Os conflitos em Dois irmãos}

A obra Dois irmãos também apresenta os dramas de uma família árabe que vive na cidade de Manaus. Assim como em Relato de um certo oriente, o autor Milton Hatoum desfaz e refaz alguns estereótipos, imaginários e representações, porém, coloca em segundo plano a ideia de que a região amazônica é meramente exótica. 0 autor assume uma postura descolonizadora, narrando uma história que começa no início do século XX, passando por dois ciclos econômicos da borracha na Amazônia, por duas guerras mundiais, chegando até o Golpe de 1964 no Brasil.

A obra relata a história de uma família árabe composta pelo casal Zana e Halim, a filha Rânia, e os gêmeos Omar (Caçula) e Yaqub: "ela, Zana, mandava e desmandava na casa, na empregada, nos filhos. Ele [Halim], paciência só, um Jó apaixonado e ardente, aceitava, engolia cobras e lagartos, sempre fazendo as vontades dela (...)" (HATOUM, 2000, p. 54).
Os dois rapazes apresentam um relacionamento conflituoso desde a infância e se desentendem violentamente na adolescência por causa do amor da jovem Lívia. Em uma sessão de cinematógrafo na casa dos vizinhos, Omar agride Yaqub fisicamente, quebrando uma garrafa no rosto dele e deixando-o marcado para sempre com uma cicatriz: "Depois, o barulho de cadeiras atiradas no chão e o estouro de uma garrafa estilhaçada, e a estocada certeira, rápida e furiosa do Caçula. 0 silêncio durou uns segundos. E então o grito de pânico de Lívia ao olhar o rosto rasgado de Yaqub" (HATOUM, 2000, p. 28).

Logo após esse episódio, o filho agredido é enviado contra sua vontade para uma aldeia remota no Líbano, terra dos pais, para morar com alguns amigos da família. Em vários momentos na obra, ele deixa bem claro o quanto essa experiência foi ruim: "ele me disse que nunca ia se esquecer do dia em que saiu de Manaus e foi para o Líbano. Tinha sido horrível. 'Fui obrigado a me separar de todos, de tudo... não queria'” (HATOUM, 2000, p.115-116).

Yaqub retorna a Manaus cinco 
anos depois e tem dificuldades de se adaptar tanto com a língua portuguesa quanto com o irmão. Contudo, permanece por pouco tempo na casa dos pais, pois se torna um bom aluno e recebe incentivo para ir embora da cidade. Com o apoio do professor Bolislau, ele pede à família para estudar em São Paulo e é atendido. Sua partida acontece em 1950. "Inflexível foi o próprio Yaqub, que enfrentou a resistência da mãe quando informou, no Natal de 1949, que ia embora de Manaus" (HATOUM, 2000, p. 38).

Omar, filho preferido de Zana, não gosta de estudar e de trabalhar, vive constantemente em confusão. Prefere passar o seu tempo com bebidas e mulheres, gastando o dinheiro da família:

Omar mal percebia o vulto arqueado sob o alpendre. Ia direto ao banheiro, provocava em golfadas a bebedeira da noite, cambaleava ao tentar subir a escada; às vezes caía, inteiro, o corpanzil suado, esquecido da alquimia da noite. Então ela saía da rede, arrastava o corpo do filho até o alpendre e acordava Domingas: as duas o desnudavam, passavam-lhe álcool no corpo e o acomodavam na rede. Omar dormia até meiodia. 0 rosto inchado, engelhado pela ressaca, rosnava pedindo água gelada, e lá ia Domingas com a bilha: derramava-lhe na boca aberta o líquido que ele primeiro bochechava e depois sorvia como uma onça sedenta (HATOUM, 2000, p. 33).

Ao longo da narrativa, o Caçula pratica uma série de ações ilegais: desaparece algumas vezes, foge para os Estados Unidos com o passaporte e o dinheiro roubados do irmão, estupra a empregada Domingas e a engravida, tornase contrabandista, entre tantas outras coisas. Na maior parte das vezes, ele recebe o apoio de Zana. 0 único momento da obra em que a mãe repreende o filho é após a morte de Halim, quando ele começa a brigar com o corpo do pai já morto.

A Domingas é de origem indígena e tem um filho: "uma beleza de cunhatã, cresceu nos fundos da casa, onde havia dois quartos, separados por árvores e palmeiras" (HATOUM, 2000, p. 64). Seu sonho era a liberdade: "meio escrava, meio ama, 'louca para ser livre', como ela me disse certa vez, cansada, derrotada, entregue ao feitiço da família" (HATOUM, 2000, p. 67). O filho Nael é o narrador da história. Ele é fruto do estupro praticado por Omar: "Uma noite ele entrou no meu quarto, 
fazendo aquela algazarra, bêbado, abrutalhado... Ele me agarrou com força de homem. Nunca me pediu perdão" (HATOUM, 2000, p. 241). Apesar do conhecimento de toda a família sobre a violência sofrida, ele não foi questionado e nem punido quanto às suas ações.

Yaqub se casa com Lívia em São Paulo, Omar tem alguns amores conflituosos (Dália e Pau-Mulato), que não são incentivados pela mãe ciumenta. Halim não concorda com as atitudes do filho Omar, mas se orgulha do profissional que se tornou Yaqub na cidade grande. Rânia prefere a vida de solteira e o trabalho no comércio da família.

Em pouco tempo, Rânia começou a vender, comprar e trocar mercadorias. Conheceu os regatões mais poderosos e, sem sair de Manaus, sem mesmo sair da rua dos Barés, soube quem vendia roupa aos povoados mais distantes. Fez um acordo com esses regatões, que no início a desprezaram; depois, acreditaram ou fingiram acreditar que Halim se escondia por trás da negociante astuta (HATOUM, 2000, p. 95).

Após a morte de Halim e Domingas, Rânia entrega o sobrado da família como pagamento de uma dívida de Omar. 0 negócio de entrega da casa foi feito por Yaqub, como forma de se vingar tanto do irmão quanto da mãe. Zana vai morar com o Rânia em outra residência até sua morte. Nael permanece em uma parte do terreno da casa da família que lhe foi dado e torna-se professor do Liceu, escola onde estudou. Como segunda parte da sua vingança, Yaqub denuncia o irmão por uma agressão física, por isso ele vai preso e condenado a dois anos e sete meses de reclusão.

Enquanto os problemas familiares se desenvolviam, Manaus era uma "mistura de gente, de línguas, de origens, trajes e aparências" (HATOUM, 2000, p. 53). Às vezes movimentada, outras vezes, um marasmo. Ora em desenvolvimento ora em declínio. A década de 1950 foi de penúria em Manaus, a vida só melhorara após a década de 1960 com o processo de integração da Amazônia ao restante do país que trouxe investimentos e trabalhadores: "Manaus está cheia de estrangeiros, mama. Indianos, coreanos, chineses... 0 centro virou um formigueiro de gente do interior... Tudo está mudando em Manaus" (HATOUM, 2000, p. 223).

\section{A Amazônia urbana de Hatoum}

Segundo Francisco Foot 
Hardman (2009), a Amazônia é uma construção discursiva e sua representatividade é constituída a partir de um imaginário. Nesse sentido, a região está eivada de lugares-comuns, relatos e ficções, que validam seu topos geográfico como espaço de homogeneização. Ainda de acordo com o pesquisador, isso acontece nos locais onde a "história ainda não conseguiu fixar marcas simbolicamente eficazes, os cenários são descritos como de geografias selvagens, natureza bruta, populações errantes e dispersas" (HARDMAN, 2001, p. 297).

Por isso, é relevante estudar essas obras de Hatoum que não homogeneízam por completo a vida na região amazônica, dando espaço para os saberes e dizeres dos diferentes povos que nela habitam. A paisagem natural está presente na obra hatouniana, porém, as disputas, os relatos da memória, os dramas familiares são intensos e norteiam o andamento do enredo.

Hatoum se afasta de algumas representações que afirmam que os moradores da região amazônica brasileira estão intrinsecamente relacionados à floresta. Como morador da cidade de Manaus, o escritor busca atribuir novos sentidos à Amazônia que ele conhece e dá destaque para a parte urbana. As percepções sociais da narrativa dele não são neutras. Ele faz escolhas que diferem dos demais autores da região com o intuito de produzir novas representações, pois elas "produzem estratégias e práticas (sociais, escolares, políticas) que tendem a impor uma autoridade à custa de outros [discursos], por elas menosprezadas" (CHARTIER, 2002, p. 17).

Ele traz para sua obra o universo dos migrantes árabes, que vivem, se vingam, brigam, trabalham, adoecem, se relacionam com os autóctones. Enquanto isso, os espaços cidade-floresta também estão constituídos em suas obras, mas não se sobrepõem aos conflitos das personagens. Assim como Hatoum, as personagens também são urbanas. Em Relato, a narradora do livro, por exemplo, é uma moradora da cidade e não tem relação de afinidade com a selva:

Lembro também de suas exaustivas incursões à floresta, onde ele [Dorner] permanecia semanas e meses, e ao retornar 
afirmava ser Manaus uma perversão urbana. 'A cidade e a floresta são dois cenários, duas mentiras separadas pelo rio', dizia. Para mim, que nasci e cresci aqui, a natureza sempre impenetrável e hostil. Tentava compensar essa impotência diante dela contemplando-a horas a fio, esperando que o olhar decifrasse enigmas, ou que, sem transpor a muralha verde, ela se mostrasse mais indulgente, como uma miragem perpétua e inalcançável. Mais do que o rio, uma impossibilidade que vinha de não sei onde detinha-me ao pensar na travessia, na outra margem. Dorner relutava em aceitar meu temor à floresta, e observava que o morador de Manaus sem vínculo com o rio e com a floresta é um hóspede de uma prisão singular: aberta, mas unicamente para ela mesma. 'Sair desta cidade', dizia Dorner, 'significa sair de um espaço, mas sobretudo de um tempo' (HATOUM, 2008, p. 93).

As duas obras estudadas revelam aspectos da decadência econômica e social de Manaus, ao mesmo tempo em que discorrem sobre o conflito entre desenvolvimento e modernidade. Mais uma vez, rompe-se com as narrativas literárias que costumeiramente apresentam as ruínas dos seringais e dos seringueiros pós-ciclos da borracha, desconsiderando as problemáticas que atingem as urbes amazônicas. Essa decadência está na passagem a seguir de Dois irmãos (2000): "O filho falou da viagem e o pai lamentou a penúria em Manaus, a penúria e a fome durante os anos de guerra" (HATOUM, 2000, p. 14).

Nessa obra, o arcaico também aparece como parte da decadência e é representado pelo comércio de Halim na época em que vendia quinquilharias, mas quando Rânia assume os negócios da família, o comércio passou a vender produtos importados que simbolizavam o moderno, o avanço pelo qual todos passavam coletivamente na cidade.

Rânia dirigiu a reforma da loja. (...) Mandava e desmandava, cuidava do caixa, do estoque e das dívidas dos caloteiros. Acabou de vez com a venda a fiado, 'uma filantropia que não combina com o comércio'. Publicou anúncios nos jornais e nas estações de rádio, mandou imprimir folhetos de propaganda. Fez uma promoção de mercadorias e torrou o encalhe, as coisas velhas, de um outro tempo.

Ela acreditava na moda, e reverenciou a moda do momento (HATOUM, 2000, p. 130).

Nestor Canclini (2006) afirma que a América Latina, obviamente incluindo a Amazônia, teve um modernismo exuberante com 
uma modernização deficiente, uma vez que a colonização se deu por nações europeias também deficientes. As ondas de modernização no final do século XIX e início do XX, observadas na descrição da cidade de Manaus, são impulsionadas pelos intelectuais europeizados, pela contribuição de migrantes, entre outros aspectos (MENDES, 2013). Porém, no decorrer do século $\mathrm{XX}$, os investimentos na região não são suficientes para levar estabilidade para a população, observa-se isso nos dois ciclos da borracha, no processo de integração Amazônia-Brasil pós 1950 (a operação movimentou grande quantidade de recursos para o projeto de desenvolvimento da região amazônica. Era preciso investir na região porque ela era vista como fonte de recursos naturais que despertava interesse internacional, logo poderia trazer benefícios financeiros para o Brasil) até no suposto progresso que chega com o Golpe de 1964.

Relato faz referências à vida portuária de Manaus, aos negócios que surgiam e desapareciam na cidade, as mudanças econômicas que os moradores da cidade foram obrigados a viver ao longo do tempo. Na passagem que se segue, a narradora, recém-chegada nessa Manaus em transição, estranha encontrar alguns prédios intactos, assim como estranha a sujeira e o descuido de tantos outros lugares da cidade:

A vazante havia afastado o porto do atracadouro, e a distância vencida pelo mero caminhar revelava a imagem do horror de uma cidade que hoje desconheço: uma praia de imundícies, de restos de miséria humana, além do odor fétido de purulência viva exalando da terra, do lodo, das entranhas das pedras vermelhas e do interior das embarcações. Caminhava sobre um mar de dejetos, onde havia tudo: casa de frutas, latas, garrafas, carcaças apodrecidas de canoas, e esqueletos de animais. Os urubus, aos montes buscavam com avidez as ossadas que apareceram durante a vazante, entre objetos carcomidos que foram enterrados há meses, há séculos (HATOUM, 2008, p. 141).

A obra enfatiza a precariedade urbana após os dois ciclos da borracha e o quanto era difícil para as pessoas que se deslocavam do interior para a cidade se adaptar a uma nova moradia às margens dos rios e em condições adversas:

Dali podíamos ver os barrancos dos Educandos, o imenso igarapé que separa o bairro anfíbio do centro de Manaus. Era 
a hora do alvoroço. 0 labirinto de casas erguidas sobre troncos fervilhava: um enxame de canoas navegava ao redor das casas flutuantes, os moradores chegavam no trabalho, caminhavam em fila sobre as tábuas estreitas, que formam uma teia de circulação. Os mais ousados carregavam um botijão, uma criança, sacos de farinha; se não fossem equilibristas, cairiam no Negro. Um ou outro sumia na escuridão do rio e virava notícia (HATOUM, 2000, p. 120).

Em contrapartida, Dois irmãos se estende até a década de 1960, portanto é possível observar também o avanço econômico que chega com os investimentos durante a ditadura militar: "ouvira dizer que Manaus crescia muito, com suas indústrias e seu comércio. Viu a cidade agitada, os painéis luminosos com letreiros em inglês, chinês e japonês" (HATOUM, 2000, p. 226).

Grande parte das obras de expressão amazônica se passa durante os dois primeiros ciclos da borracha (final dó século XIX e início do XX), por isso não é comum a discussão sobre os efeitos da Ditadura Militar (1964-1985) na literatura sobre a região. Milton Hatoum rompe com mais esse estigma e usa seus personagens para narrar não só os investimentos econômicos do período, mas também a violência e o medo sentido pelos moradores de Manaus por causa da presença dos militares:

Ele sabia que Manaus se tornara uma cidade ocupada. As escolas e os cinemas tinham sido fechados, lanchas da Marinha patrulhavam a baía do Negro, e as estações de rádio transmitiam comunicados do Comando Militar da Amazônia. Rânia teve que fechar a loja porque a greve dos portuários terminara num confronto com a polícia do Exército. Halim me aconselhou a não mencionar o nome de Laval fora de casa. Outros nomes foram emudecidos. A tarja preta que cobria uma parte da fachada do liceu fora arrancada e as portas do prédio permaneceram trancadas por várias semanas (HATOUM, 2000, p. 198).

Durante muito tempo prevaleceu nos discursos literários um constante apagamento e/ou estranhamento de alguns fatos históricos, caso da Ditadura, assim como permaneceu um apagamento das populações amazônicas (caboclos, indígenas) e um enfoque restrito aos aspectos ecológicos. E sabe-se que a manutenção desse desaparecimento impede a visibilidade e a compreensão das trocas culturais existentes na região. Por isso, a necessidade 
de reconstruir e reinterpretar narrativas e representações corrigindo o apagamento dos povos e observando as diversidades culturais e sociais existentes no norte do Brasil.

Nas duas obras analisadas, a natureza é deslocada do primeiro plano e surge em menor proporção. Observam-se, prioritariamente, as composições humanas: a busca das identidades dos narradores - Nael e a filha de Emilie - as paixões de Zana, Halim, Emilie, as violências sofridas por Domingas e Anastácia, as vinganças de Omar e Yaqub, os desencantos com a vida de Rânia.

A ação de inclusão dos migrantes pelo autor Milton Hatoum não é isolada na literatura, mas traz à tona os povos que contribuíram com a formação social, econômica, política e histórica da região amazônica. Tanto em Relato quanto em Dois irmãos, quebram-se alguns estereótipos e reducionismos porque se rompe com o fio do discurso tradicional a respeito da Amazônia, mas conservamse tantas outras representações, caso do imaginário a respeito dos povos árabes: os patriarcas trabalham com o comércio; as mães não têm trabalho formal, mas são constituídas de poder simbólico, pois cuidam das casas, da educação dos filhos e guardam os segredos de família.

Apesar da tentativa de inclusão das minorias amazônicas na literatura hatouniana, destaca-se que os indígenas e todos os seus aspectos culturais permanecem

parcialmente silenciados nas duas obras. As mulheres indígenas aparecem nas narrativas de Hatoum, frequentam a área urbana, têm trabalho informal, mas ainda são narradas de forma marginalizada. Mesmo na cidade, elas continuam sendo discriminadas, vítimas de violência física:

(...) eles [os filhos dos donos da casa] nunca suportaram de bom grado que uma índia [Anastácia] passasse a comer na mesa da sala, usando os mesmos talheres e pratos, e comprimindo com os lábios o mesmo cristal dos copos e a mesma porcelana das xícaras de café (HATOUM, 2008, p.109).

Isso é demonstração de que ainda há, portanto, barreiras que precisam ser ultrapassadas no que se refere ao conhecimento e à valorização das diversas populações que habitam o norte 
do Brasil. No caso das mulheres indígenas em Hatoum, elas precisam expressar seus valores, desejos, opiniões e culturas, devendo escolher onde e como querem viver. Não podem só absorver o modo de vida dos patrões, os hábitos, a religião, a gastronomia.

A Amazônia de Hatoum é plural, híbrida, multifacetada, mas ainda apresenta lacunas no que se refere à desconstrução de alguns sentidos sobre a região. A Manaus do autor ainda aparece como espaço de mitos e lendas, remetendo à literatura que comumente relaciona moradores da floresta com histórias encantadas. 0 boto, por exemplo, faz parte da vida dos caboclos da Amazônia brasileira, assim como dos migrantes que na região vivem. São muitas as histórias que alimentam o imaginário da população local, desde o animal que cativa os humanos, a cidade encantada no fundo do rio e/ou a presença da cobra grande.

Em Dois irmãos, Domingas afirma que Yaqub era frequentemente alvo de olhares femininos, era um conquistador, por isso ela faz uma comparação entre ele e o boto: "Esse gêmeo tem olhão de boto; se deixar, ele leva todo mundo para o fundo do rio" (HATOUM, 2000, p. 30). 0 comentário da indígena sustenta a ideia de que os mitos e as lendas estão continuamente entrelaçados ao imaginário dos sujeitos locais, mesmo os urbanizados.

\section{Considerações finais}

Diante do exposto, não se pode pensar a região amazônica de forma linear, suprimindo-se os tempos diferenciados da floresta e o da cidade, bem como da gente que ali vive. Durante longo período (século $\mathrm{XX}$ ), a literatura mais conservadora acompanhada do realismo naturalista tentou 'apagar' as diferenças de espaço de convivência, perdendo-se parte importante dos processos que compõem a formação social, política e econômica da Amazônia.

Contudo, autores como Milton Hatoum caminham em direção contrária aos que veem a Amazônia como terra uniforme, observando as multiplicidades e divergências de seus povos. Relato de um certo oriente e Dois irmãos mostram que não há nada de definitivo na Amazônia, a vida está em construção, é conflituosa, 
mutável e segue fluida.

Ambas as narrativas podem contribuir com os fios que tecem as narrativas amazônicas. A literatura de Hatoum é de caráter crítico e questionador, pois a função da obra literária é ser território de contestação. Ela deve ser sempre espaço para o exercício da inquietação, criando discursos desestabilizadores em vez de apenas repetir o passado com a disseminação de conceitos previamente dados.

\section{Referências}

BHABHA, H. K. O local da cultura. Tradução de Myriam Ávila, Eliana Lourenço, Gláucia Renate. Belo Horizonte: Ed. UFMG, 2013.

CANCLINI, N. G. Culturas híbridas: estratégias para entrar e sair da modernidade. $3^{\mathrm{a}} \mathrm{ed}$, São Paulo: USP, 2006.

CHARTIER, R. A história cultural: entre práticas e representações. Tradução Maria Manuela Galhardo. Algés, Portugal: Difel, 2002.

GURGEL, L. H. Não há literatura sem memória. Revista $\mathrm{Na}$ ponta do lápis. Ano IV, no 8. AGWM Editora e produções editoriais, junho/2008. Disponível em: https://goo.gl/ R4dUxx. Acesso em 15 jan. 2017.

HARDMAN, F. F. Antigos modernistas. In: A brasilidade modernista. São Paulo: Companhia das Letras, 2001. HARDMAN, F. F. A invenção da Hileia: Euclides da Cunha, a Amazônia e a literatura moderna. São Paulo: Editora UNESP, 2009.

HATOUM, M. Dois irmãos. São Paulo: Companhia das letras, 2000.

HATOUM, M. Relato de um certo oriente. São Paulo: Companhia das letras, 2008.

HATOUM, M. A cidade ilhada: contos. São Paulo: Companhia das letras, 2009.

MENDES, F. M. M. Identidades híbridas: o lugar das personagens ficcionais na obra Coronelde Barranco. 2008. Dissertação (Mestrado em Letras: Linguagem e Identidade) Universidade Federal do Acre - UFAC, Rio Branco, 2008. Disponível em https://goo.gl/RHkmco. Acesso em 14 jan. 2017.

MENDES, F. M. M; QUEIRÓS, F. A. T.. Do inferno ao paraíso: narrativas sobre a Amazônia brasileira. Revista Igarapé. 2014. Disponível em: https://goo.gl/6oFDgz. Acesso em: 14 jan. 2017.

SILVA, J. da. Panorama da produção literária de Milton Hatoum e de sua recepção, em homenagem aos vinte anos de Relato de um certo oriente. Somanlu. ano 10, n.1, jan/jun, 2010. Disponível em: https://goo. gl/31vaAs. Acesso em 15. Jan. 2017. 